\title{
Geochemical evaluation of Khami Group oils in the South Dezful Embayment, Iran
}

\author{
Bahram Alizadeh $^{1,2} \cdot$ Amir Abbas Jahangard $^{1} \cdot$ Majid Alipour $^{1} \cdot$ Ahmadreza Gandomi Sani $^{3}$
}

Published online: 10 September 2020

(c) The Author(s) 2020

\begin{abstract}
An integrated geochemical study, including GC, GC-MS and stable carbon isotope analyses, was conducted on a suite of oil samples from the Khami Group reservoirs to provide new insights into the Upper Jurassic-Lower Cretaceous petroleum system in the South Dezful Embayment. Possible source rocks were also characterized using Rock-Eval pyrolysis to address the likely potential source rocks. The oil samples representing four major reservoirs (Surmeh, Fahliyan, Gadvan and Dariyan) constitute a single genetic oil family according to bulk and biomarker parameters. High API $\left(>38^{\circ}\right)$, highly saturated hydrocarbons (Sat $>65 \%)$, very low asphaltene content $(\mathrm{Asp}<2 \%)$ and raised saturates/aromatics ratio (Sat/Aro $>2)$ are the bulk diagnostic characteristics of the studied oils implying more dominant terrigenous nature of the precursor organic matter. The predominance of $\mathrm{C}_{29}$ regular steranes ( $\left.40 \%\right)$, presence of $\mathrm{C}_{29}$ Ts as well as very low gammacerane $(<10 \%)$ and moderate $\mathrm{C}_{35} / \mathrm{C}_{34}$ homohopane $(<1)$ are consistent with the mixed marine-terrigenous dysoxic organic matter input. The oils are assumed to be originated from Early Cretaceous source rocks at the peak of the oil generation window in a kitchen area located to the south of the studied region (i.e., the Binak-Borazjan Trough). The hydrocarbons were migrated from this kitchen to the structurally shallow-seated reservoirs in the center and west of the Kharg-Mish local paleo-high. The Khami Group reservoirs are not effectively sealed by the thin Hith anhydrites, and the Kazhdumi Formation finally trapped the migrated hydrocarbons. This study improves our knowledge regarding one of the active petroleum systems in the South Dezful Embayment, enhancing petroleum exploration success by navigating further drillings into the more prosperous targets.
\end{abstract}

Keywords South Dezful Embayment $\cdot$ Khami group oils $\cdot$ Petroleum system · Oil family classification · Biomarker · Carbon isotope ratio

\section{Introduction}

The Upper Jurassic-Tertiary sedimentary succession of the South Dezful Embayment is the host for most of the oil and gas reserves in the southwest of Iran. The Upper Cretaceous-Tertiary petroleum system is broadly discussed (Alizadeh et al. 2018, 2012; Bordenave 2002, 2014; Bordenave and Burwood 1990, 1995; Bordenave and Hegre 2010),

Bahram Alizadeh

alizadeh@scu.ac.ir

1 Department of Petroleum and Sedimentary Basins, Faculty of Earth Sciences, Shahid Chamran University of Ahvaz, Ahvaz, Iran

2 Petroleum Geology and Geochemistry Research Center (PGGRC), SCU, Ahvaz, Iran

3 Exploration Directorate, National Iranian Oil Company (NIOC EXP), Tehran, Iran while the Upper Jurassic-Lower Cretaceous petroleum system of this area has been neglected inadvertently. This study tried to throw light on this ambiguity. On the other hand, the stratigraphy and burial history of the South Dezful Embayment have been studied in recent years (Bordenave 2002; Bordenave and Hegre 2010; Opera et al. 2013). The Jurassic petroleum system of adjacent areas (e.g., Saudi Arabia, Qatar, Kuwait and Iraq), which constitute the time and lithostratigraphic equivalents of Iranian Zagros petroleum basin, has also been studied in detail (Abeed et al. 2013; AlHusseini 2008; Cole et al. 1994; Pollastro 2003).

In this study, various aspects of the relatively unknown Upper Jurassic-Lower Cretaceous petroleum system of the South Dezful Embayment are discussed. Oil samples from reservoirs of the Khami Group (i.e., Surmeh, Fahliyan, Gadvan and Dariyan reservoirs) are included in the discussion. By using a multi-disciplinary approach, the results from this study have enabled us to disclose connectivity between the 
Upper Jurassic Surmeh and the Lower Cretaceous Fahliyan/ Khalij/Dariyan reservoirs in the study area. In addition, the genetic relationships between oils originating from east and west of the Kharg-Mish Basement Fault have been defined.

Lack of mature samples of the possible source rocks, as well as the oil samples from the deep Khami reservoirs in the main kitchen area (Binak-Borazjan depression), has created a limitation to conduct a well-established biomarker-isotopic source-oil correlation. To overcome this limitation, here, an indirect predictive approach had to be performed for source rock characterization, including source rock aging, maturity and organic facies, solely based on evidence from the oil fingerprints.

Integrating the source rock screening analysis with biomarker and isotopic fingerprinting of the reservoir oils in Khami Group has enabled us to illustrate the overall sketch of Upper Jurassic-Lower Cretaceous petroleum system in the southern part of the Dezful Embayment, which has not been accomplished before in the previous studies. These findings have practical implications for addressing the possible oil-source rock relationships and draw a conceptual migration pathway of the studied oils within the area. This decreases the exploration risk and provides guidelines for future drilling activities for oil field development purposes.

Briefly, this study was commenced with biomarker fingerprinting of the Khami reservoir oils verified by the isotopic data. Later the possible source rocks were discussed in terms of their organic richness, thermal maturity and petroleum potentials. Geological constraints added complementary details and improved the knowledge of the likely source of the hydrocarbons. Finally, the best possible source rocks were introduced and the general migration pathways were illustrated to complete the scenario of the Upper Jurassic-Lower Cretaceous petroleum system in the Southern part of the Dezful Embayment.

\section{Geological setting}

The Dezful Embayment is a part of the folded and faulted Zagros, a basin with an initial horst-graben origin, which is complicated later by structural dynamism (controlled by basement faults) in conjunction with halo-kinetic movements (Bordenave and Hegre 2005; Fard et al. 2006; Letouzey and Sherkati 2004). Repeated activation of NW-SE and NE-SW basement faults, mostly inherited from Precambrian orogenic and epeirogenic phases, has resulted in vertical and lateral facies changes during the evolution of Zagros basin (Bahroudi and Talbot 2003; Hessami et al. 2001; Sherkati and Letouzey 2004). Our study area is located between the Qatar-Kazerun Fault (QKF) from the west and the Kharg-Mish Fault (KMF) from the east (Fig. 1). The Mountain Front Fault (MFF) and the Zagros Frontal Fault (ZFF), respectively, define the northern and southern boundaries of this area.

During the Late Permian-Middle Cretaceous (255-92 Ma), the South Dezful Embayment was the northeast passive margin of the Arabian plate seated in $25^{\circ}-30^{\circ}$ paleo-latitudes (Alsharhan 2014; Beydoun et al. 1992; Bordenave and Hegre 2005; Navabpour and Barrier 2012; Sepehr and Cosgrove 2004). The establishment of the

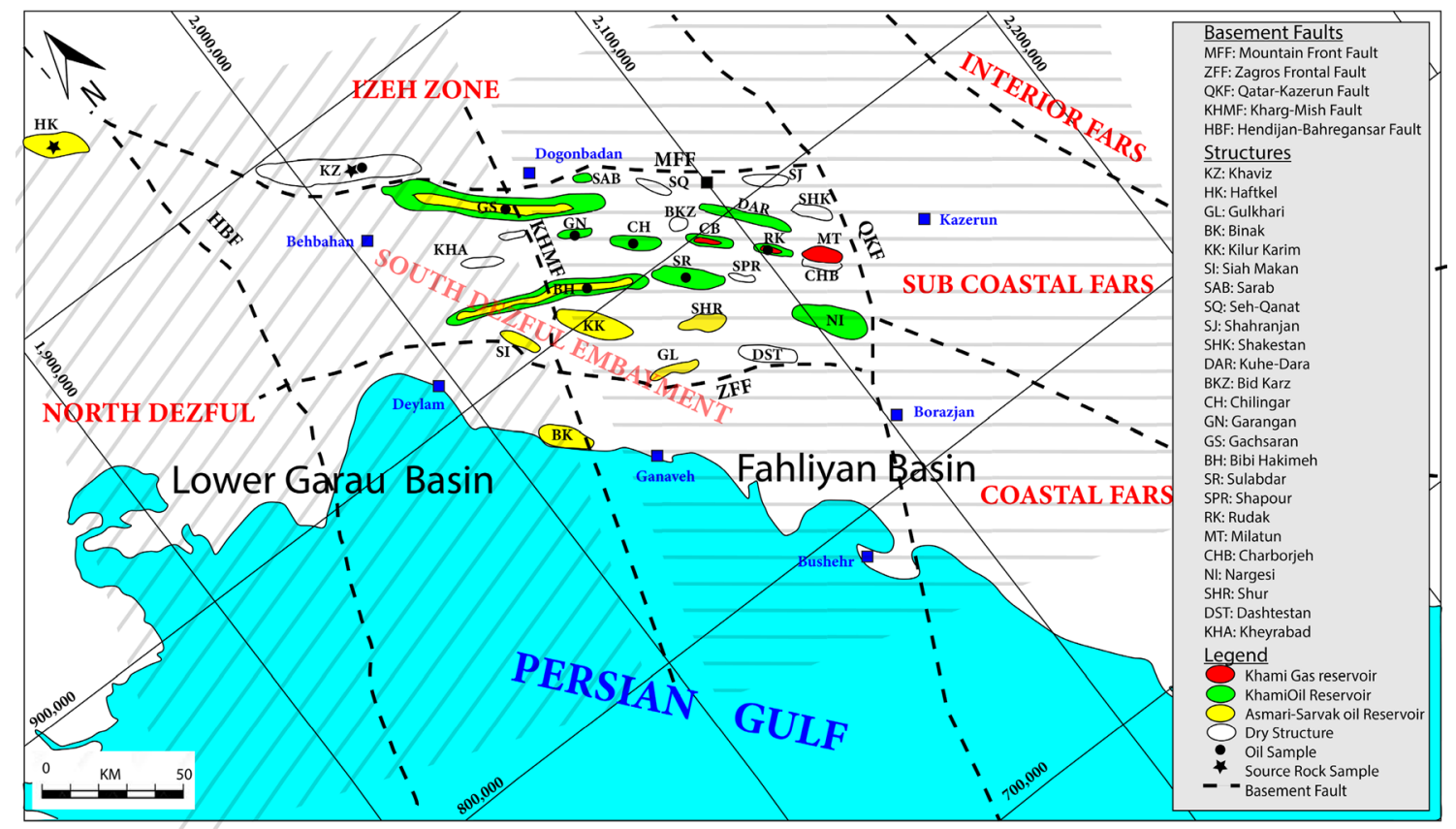

Fig. 1 Structural setting and location map of the studied reservoirs in the South Dezful Embayment 
compressional regime beginning by mid-Turonian ophiolite obduction transformed the basin into an active margin. Finally, the basin was filled with a large amount of flysch clastic sediments (Aghajari foredeep facies) in the Zagros foreland basin during the last phases of Alpine orogeny (Ziegler 2001).

The Mesozoic through Cenozoic succession in the Dezful Embayment contains prolific source rock intervals (Alizadeh et al. 2012), interlayered with porous fractured reservoirs and effective seals (Murris 1980; Ziegler 2001). Reactivation and movements of ancient basement faults and Zagros folding are suggested to have strong control over trap charge dynamics and preservation of accumulated hydrocarbons (Beydoun et al. 1992; Beydoun 1993; Bordenave and Hegre 2005).

Strike-slip movements along the Qatar-Kazerun and Kharg-Mish faults were induced by the Cenomanian orogeny (Ziegler 2001). Their activations resulted in the formation of major structural depression (i.e., the Binak-Borazjan depression) and the appearance of the paleo-relief structure (the Kharg-Mish paleo-high). This fault-related structure was well observed as a paleo-high from regional isopach maps and thinning/truncation patterns observed on seismic profiles (Baniasad et al. 2017; Bordenave 2014; Sherkati and Letouzey 2004).

The Middle Jurassic (Late Bathonian-Kimmeridgian) Surmeh Formation is the deepest strata drilled in the South Dezful Embayment and comprises outer ramp sediments. As the time equivalent of the Arab Formation of the Persian Gulf and Saudi Arabia, this formation was a regressive sequence of carbonates and evaporates (Fig. 2). During the Late Jurassic (Tithonian), the time was spanned by the deposition of evaporitic facies of the Hith Formation in a retrograding basin.

Early Cretaceous tectonic movements (Berriasian-Valanginian) reactivated the Kharg-Mish Basement Fault, causing the deposition of the Lower Garau Formation (outer ramp sediments) in the west, while high-energy mid-ramp shoals prevailed in the east of this fault (i.e., the Fahliyan Formation). Shallow marine limestones of the Fahliyan Formation are composed of oolitic, pelletal and brecciated calcarenites, formed in a shallow passage from shoal to low-energy lagoon environments (van Buchem et al. 2001; Ziegler 2001).

Late Neocomian-Early Aptian shales, marls and limestones (Khalij Member) of the Gadvan Formation were deposited on a low-energy open marine carbonate ramp (van Buchem et al. 2001). The Dariyan Formation encompasses deep marine pelagic facies with intermittent anoxic conditions at the bottom, which grades into shallow marine carbonate platform sediments at the top. The argillaceous member of the Dariyan Formation, informally called the Kazhdumi Tongue, shows deep marine facies that occasionally becomes organic-rich, indicating anoxic depositional environment. The Upper Surmeh dolostones and the Upper Fahliyan grainstones constitute good quality reservoir rocks in the South Dezful Embayment (van Buchem et al. 2001).

Following the Aptian-Albian hiatus (121-98.9 Ma), the Kazhdumi basin was developed in the South Dezful Embayment and most of the Fars Province in a newly started megasequence under deep marine clastic conditions. Lithostratigraphic equivalents of the Kazhdumi Formation (i.e., the Nahr Umar and Burgan reservoir facies) were deposited to the west of the Persian Gulf (Bordenave and Burwood 1995). The depth of the Kazhdumi basin is suggested to have increased eastward, with the deepest parts occurring close to the Neo-Tethys passive margin (Bordenave 2014; Bordenave and Burwood 1995; Ziegler 2001). The relatively thick shales of the Kazhdumi Formation can act as an efficient cap rock for the Late Jurassic-Early Cretaceous carbonate reservoirs of the Khami Group throughout the South Dezful Embayment (Bordenave 2002; Nairn and Alsharhan 1997).

\section{Materials and methods}

A suite of 140 cutting samples from three probable source layers (Kazhdumi, Kazhdumi tongue and Gadvan Formations), selected out of 13 exploratory wells, were evaluated by Rock-Eval 6 pyrolysis.

Detailed geochemical analyses including hydrocarbon fractionation, stable carbon isotope analysis and gas chromatography-mass spectrometry were carried out on 16 oil samples of four different Khami Group reservoirs: including Surmeh (Upper Jurassic), Fahliyan (Neocomian), Gadvan (Barremian) and Dariyan (Aptian) Formations. A set of six oil samples were re-evaluated from the previous study (LGC 2002). The following analytical techniques were conducted on the rest of the nine oil samples in this study.

Prior to oil analysis, the de-asphalting phase was performed by adding $n$-heptane (forty times by volume) to the oils and stored at ambient temperature for eight hours minimum, in a dark place then passing through the filter paper. The maltene fractions were further separated into saturates, aromatics and resins using alumina-packed chromatography columns (stationary phase) and $n$-hexane, benzene and mixture of dichloromethane-methanol (9:1) as mobile phases, respectively. All fractions were dried under inert atmosphere (nitrogen gas) after separation (Alizadeh et al. 2018).

Both saturate and aromatic fractions were analyzed using a gas chromatograph (Hewlett Packard 5971 A) coupled with a mass spectrometer (Hewlett-Packard 5888). The temperature was programmed to begin from $40{ }^{\circ} \mathrm{C}(10 \mathrm{~min}$ isothermal), ramped to $300{ }^{\circ} \mathrm{C}$ (at a rate of $4{ }^{\circ} \mathrm{C} / \mathrm{min}$ ) and held constant for $15 \mathrm{~min}$. Helium is the carrier gas. 
Fig. 2 Simplified chronolithostratigraphic chart of the study area (Al-Husseini 2008; Alsharhan 2014; Bordenave 2014; Cohen et al. 2013; James and Wynd 1965; Gradstein et al. 2009; Ziegler 2001)

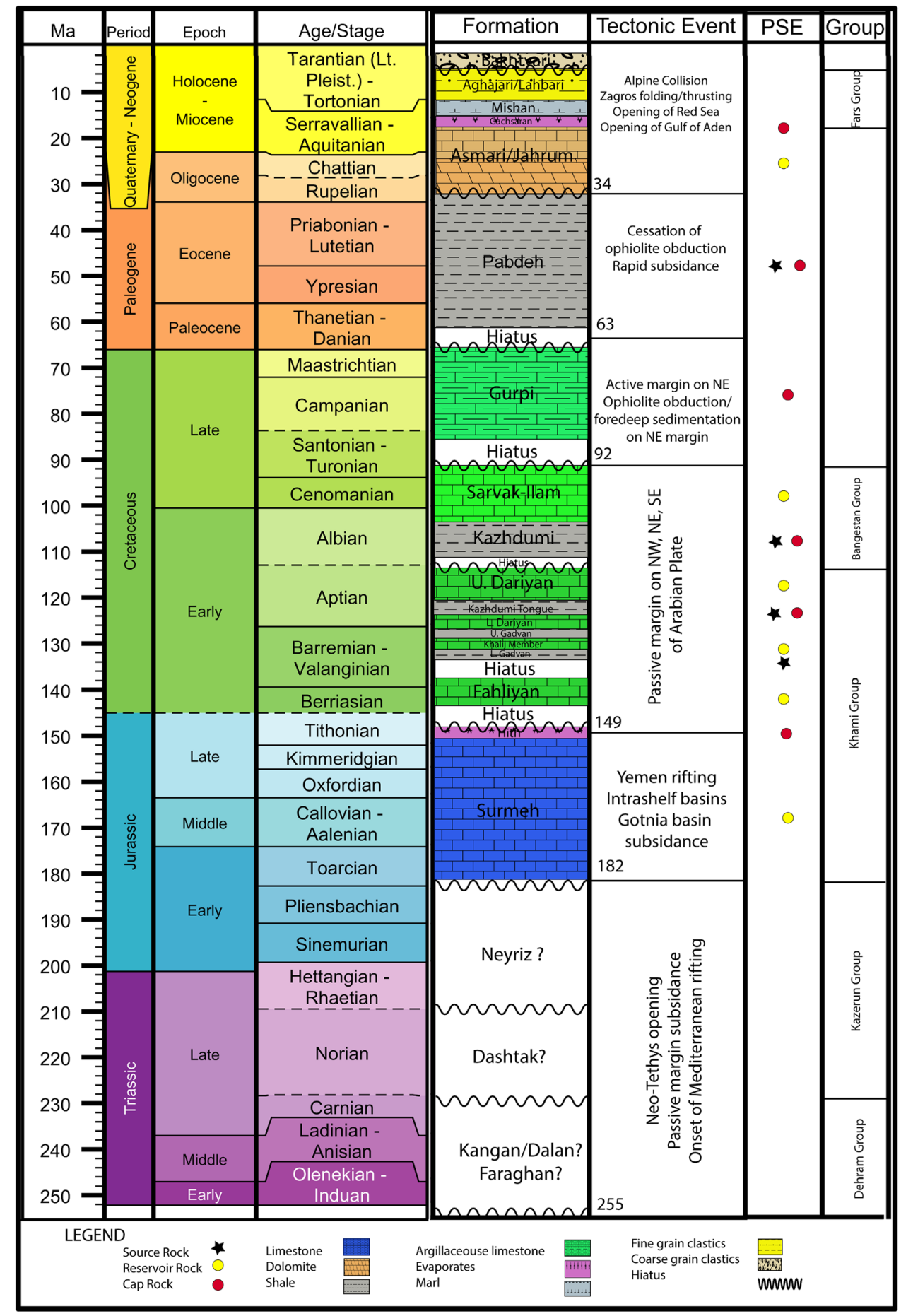

Stable carbon isotope analyses were conducted on asphaltene fractions of nine oil samples by using an elemental analyzer-isotope ratio mass spectrometer (EA-IRMS). Here, the resulting $\mathrm{CO}_{2}$ from high-temperature $\left(1000{ }^{\circ} \mathrm{C}\right)$ combustion of carbon in the sample was later introduced into a chromatographic column held under isothermal conditions.
The chromatographic peaks sequentially entering the IRMS module were separated according to their molecular mass and finally were measured by a Faraday cup universal collector array. All measurements were reported relative to the PDB standard with the analytical precision in \pm 0.02 range. 


\section{Results and discussion}

\section{Oil analysis}

\section{Bulk properties}

According to the high API gravity (38-40 API ${ }^{\circ}$ ) and the relatively high concentrations of saturated hydrocarbons ( $>59.5 \%$ ), the studied oils from the South Dezful Embayment can be classified as paraffinic to paraffinic-naphthenic (Table 1) (Tissot and Welte 1984). The asphaltene contents less than $1.5 \%$ may also reveal a high level of thermal maturity.

\section{Molecular and isotopic properties}

Thermal maturity Saturate fraction gas chromatography shows that the studied oils are not seriously affected by the biodegradation and have similar normal alkane-isoprenoid fingerprints. The predominance of $n-\mathrm{C}_{13}$ to $n-\mathrm{C}_{15}$ homologs, together with a unimodal $n$-alkane distribution, clearly indicates the high maturity of the samples (Fig. 3).

The high maturity of the studied oils is also indicated by the absence or very small amount of polycyclic aromatic hydrocarbons (PAHs) with prominent naphthalene and phenanthrene compounds in the aromatic fraction (Fig. 3). Similarly, large concentrations of thiophenic compounds $(\mathrm{DBT} / \mathrm{P}>1.5)$ in the aromatic fraction suggest that the high sulfur content of the reservoir oils can be a result of higher thermal maturity (Huang and Pearson 1999; Hughes et al. 1995). Further evidence supporting the high maturity of studied oils is provided by the high concentrations of tricyclic terpanes relative to $17 \alpha$-hopanes, the relatively large concentration of $\mathrm{C}_{19}-\mathrm{C}_{22}$ regular steranes and the sterane isomerization ratios (Fig. 4).

Homohopane isomerization ratios of $\mathrm{C}_{32} 22 \mathrm{~S} /$ $(22 \mathrm{~S}+22 \mathrm{R})$ can be used as a maturity index in crude oils and source rock extracts. The ratio rises from zero to $0.57-0.62$ during the maturation, and its specificity is limited to the early oil generation window (Ro < 0.6) (Seifert and Moldowan 1980). For oils from the South Dezful Embayment, this value ranges from 0.58 to 0.62 (Table 2; Fig. 4), indicating that the main phase of oil generation has already been reached or surpassed. The absence of $\beta \beta$ hopanes and the very low moretane/hopane ratios $(<0.16$, Table 2) clearly suggest that the studied oils have been generated by a source rock which already past the early mature stage.

Maturity-related biomarker ratios from steranes, $\mathrm{C}_{29}$ $20 \mathrm{~S} /(20 \mathrm{~S}+20 \mathrm{R})$ and $\mathrm{C}_{29} \beta \beta /(\alpha \alpha+\beta \beta)$, range between $0.51-0.53$ and $0.56-0.61$, respectively, for the studied oil samples (Fig. 4). The average values (0.52 and 0.58 , correspondingly) for these maturity indices suggest that the possible source rock was subjected to thermal maturity as high as the peak of the oil generation window (Table 2; Fig. 4) (Peters 1999).

Since hopanes and steranes maturity parameters reach their equilibrium values close to the peak oil generation, aromatic maturity parameters are used to infer about the maturity of oils in this study. The aromatization of monoaromatic to triaromatic steroids can be used as a maturity indicator based on the 253 and 231 mass chromatograms (Mackenzie et al. 1981). Values ranging from 0.60 to 0.68 for our oils suggest that they have been generated from a source rock at the peak of the oil generation window (Table 2). This is further supported by high values of TAS I/(I+II) (0.56-0.63, Table 2) (Mackenzie 1984; Peters et al. 2005). Values observed for TAS $\mathrm{C}_{20} /\left(\mathrm{C}_{20}+\mathrm{C}_{28} 20 \mathrm{R}\right)$ ratios (0.77-0.84, Table 2) also support the contention that the studied oils have been generated from a source rock at the peak of oil window (Mackenzie et al. 1981) (Fig. 5).

Rearrangement and conversion of sulfur-containing aromatics (non-biomarker maturity parameters) provide another scale of oil and source rock maturity (Boreham et al. 1988; Radke 1983, 1988; Radke et al. 1986). According to the values obtained for 4-MDBT/1-MDBT (MDR) (7.6-8.63), MPI-1 (0.93-1.06) and MNR (1.59-1.66) ratios, the studied oil samples have maturity equivalent to $0.87-0.90 \% \mathrm{R}_{\mathrm{o}}$ in the studied area (Table 2).

Source rock depositional environment The cross-plot of $\mathrm{Pr} / n-\mathrm{C}_{17}$ versus $\mathrm{Ph} / n-\mathrm{C}_{18}$ can be used to infer oxicity and organic matter input in the source rock depositional environment (Peters et al. 1999, 2005). Crude oils from the South Dezful Embayment indicate type II and mixed II/III organic matter belonging to anoxic to semi-anoxic depositional environments (Fig. 6). The $\mathrm{Pr} / \mathrm{Ph}$ ratios close to unity for the studied oils (Table 1) again support the high level of thermal maturity of the oils and have less influence from the paleo-depositional environment (Fig. 7) (Hughes et al. 1995; Moldowan et al. 1985; Peters et al. 2005; Ten Haven et al. 1988; Ten Haven et al. 1987).

The ratio of $18 \alpha(\mathrm{H})$ trisnorneohopane $\left(T_{\mathrm{S}}\right)$ to $17 \alpha(\mathrm{H})$ trisnorhopne $\left(\mathrm{T}_{\mathrm{m}}\right)$ is primarily controlled by organic facies; however, it can also be influenced by thermal maturity (Peters et al. 2005). In addition, hypersaline conditions or high clay contents in the source can increase the initial value of this ratio even in low-maturity samples (Peters et al. 2005; Waples and Machihara 1991). The linear correlation existing between the $T_{\mathrm{s}} / T_{\mathrm{m}}$ and $\mathrm{C}_{29} / \mathrm{C}_{30}$ hopane ratios (Table 2) may suggest some environmental control existing over the $T_{\mathrm{s}} / T_{\mathrm{m}}$ ratio (Connan et al. 1986; Peters et al. 2005; Zumberge 1984). However, the influence of maturity cannot be ruled out in our samples and the high $T_{\mathrm{s}} / T_{\mathrm{m}}$ ratios observed for the

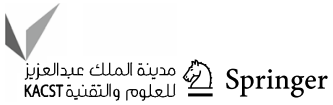




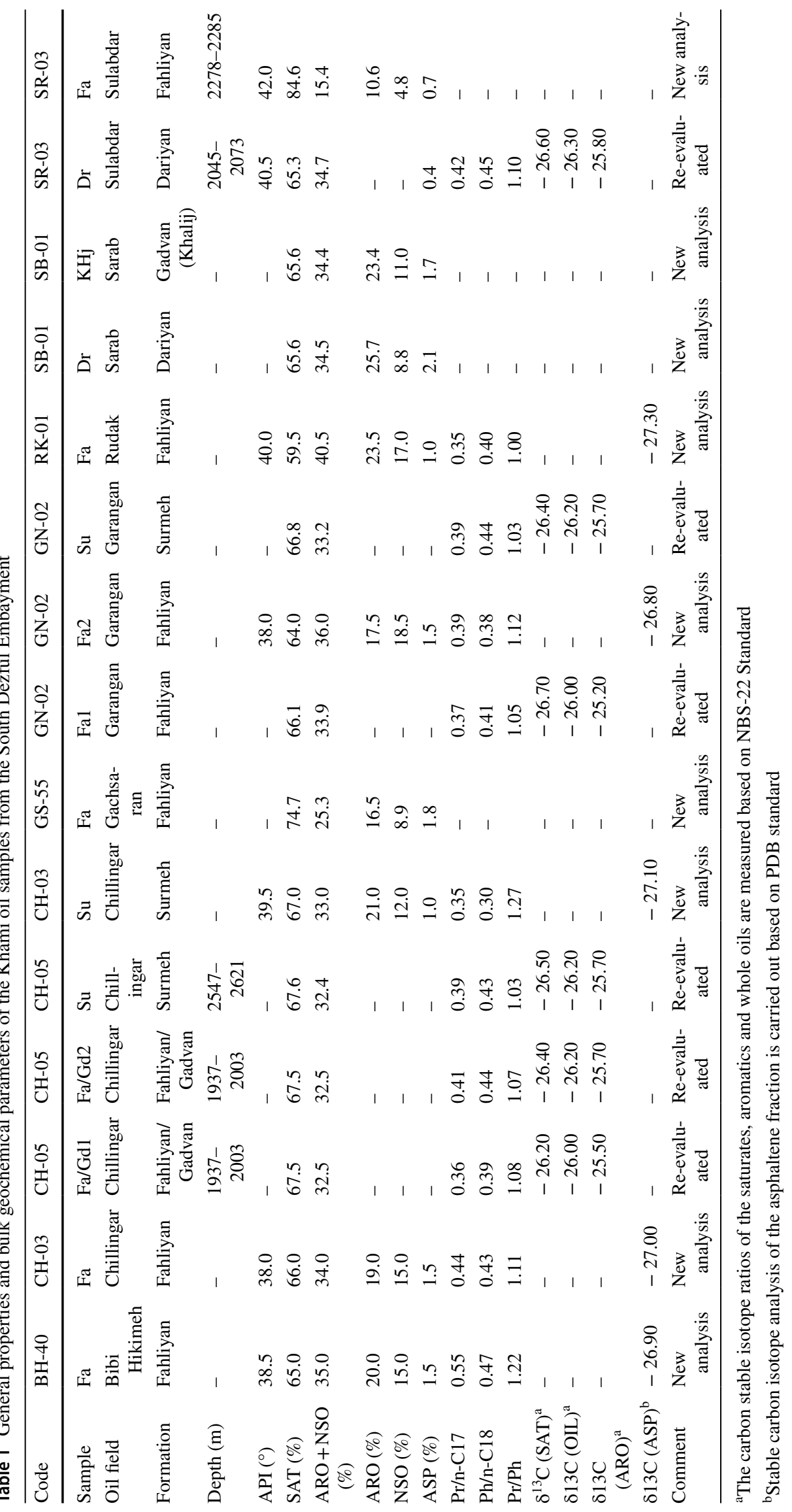


Fig. 3 Typical saturate and aromatic gas chromatograms of Khami oils in the South Dezful Embayment
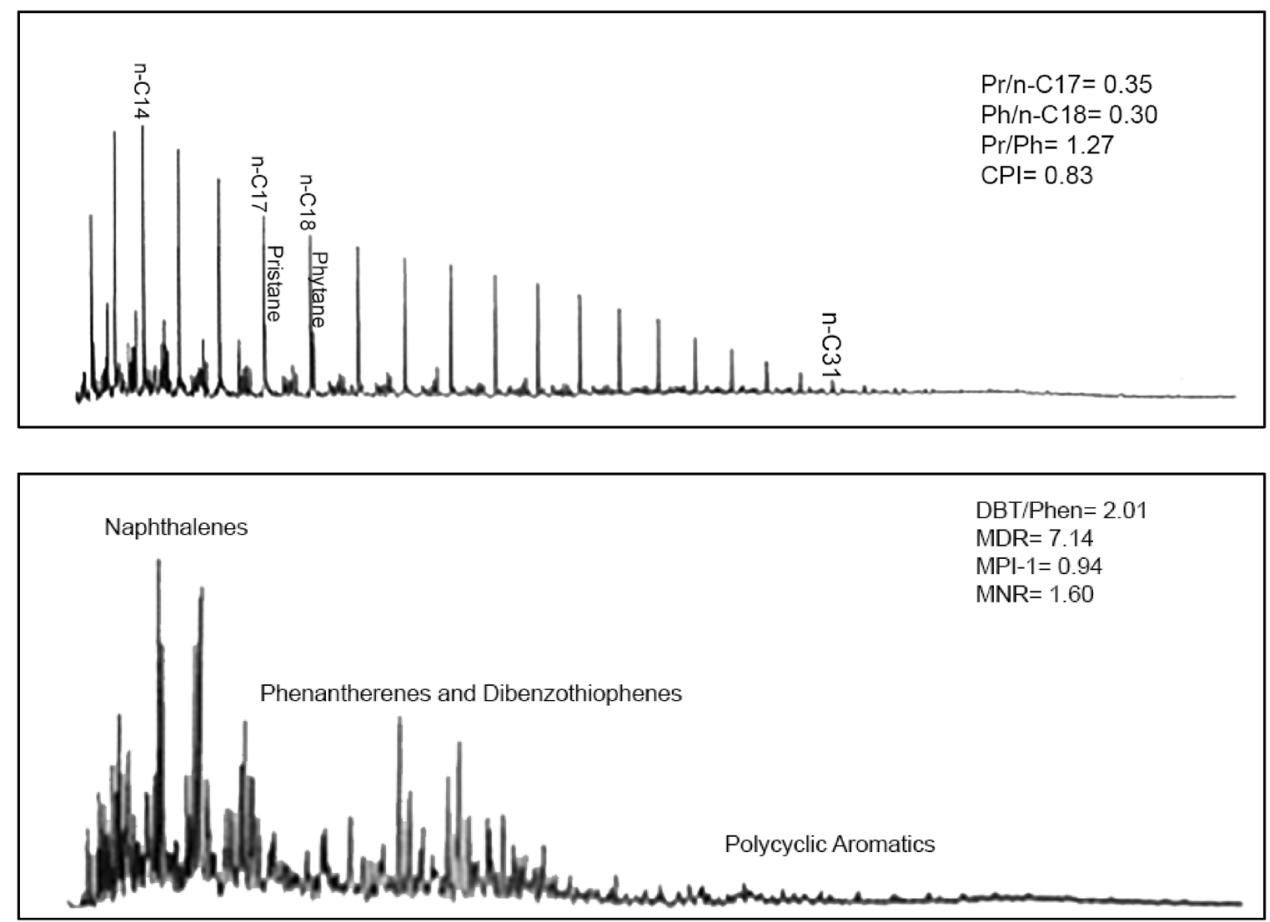

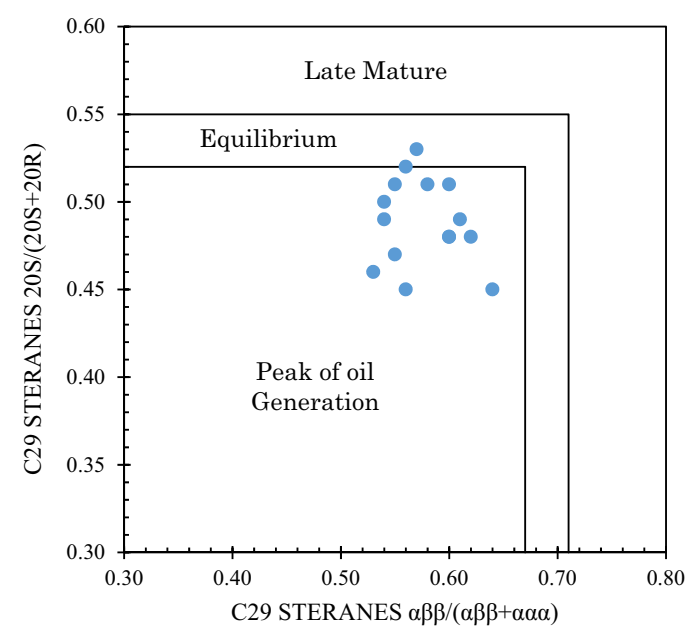

Fig. $4 \mathrm{C}_{29}$ sterane isomerization ratios for oil samples from the South Dezful Embayment. The samples fall close to the equilibrium area (marked by solid lines) (after Peters 1999)

Khami oils are a result of their higher maturity $(0.98-3.12$; Table 2) (Moldowan et al. 1986; Waples and Machihara 1991).

The stair-step reduction of $\mathrm{C}_{31}-\mathrm{C}_{35}$ homohopanes is consistent with the semi-anoxic conditions during the source rock deposition, which is confirmed by low gammacerane content. The terpane distribution patterns obtained for studied oils are also typically consistent with the source rocks deposited under shallow marine shelf environment (Peters et al. 2005) (Fig. 8). The considerable terrestrial organic matter could enter this environment based on the high tricyclic terpane concentrations as well as the predominance of regular $\mathrm{C}_{29}$ sterane in the studies oils (Fig. 8).

Generally, based on the corroborative evidence from various biomarker parameters, we can conclude that oils in Khami reservoirs from the South Dezful Embayment have originated from marine marls/argillaceous carbonates with significant terrigenous influence during deposition.

Source rock age Oleanane presence in crude oils and source rock extracts is commonly used to infer the age and organic matter input (Peters et al. 2005). The absence of oleanane in crude oils of Khami reservoirs in the South Dezful Embayment (oleanane/ $\mathrm{C}_{30}$ hopane $\sim$ zero, Table 2) proposes that the source rock should be deposited before the Early Cretaceous.

The ratio of $\mathrm{C}_{28} / \mathrm{C}_{29} \alpha \alpha \alpha 20 \mathrm{R}$ regular sterane is suggested to increase through geologic time due to the diversification of pelagic fauna in marine environments (Peters et al. 2005; Waples and Machihara 1991). Previous studies have shown that this ratio is less than 0.7 for oils generated by marine source rocks older than Upper Jurassic (Grantham and Wakefield 1988). The $\mathrm{C}_{28} / \mathrm{C}_{29}$ sterane ratio for our studied oils varies from 0.48 to 0.7 (Table 2). However, due to the predominant concentration of $\mathrm{C}_{29}$ steranes in these oils, the application of this ratio to predict source rock age is a bit risky.

The extended tricyclic terpane ratio (ETR) (Holba et al. 2001) is another age-related parameter frequently used in 


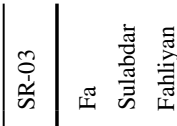

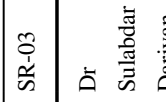

苛

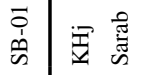

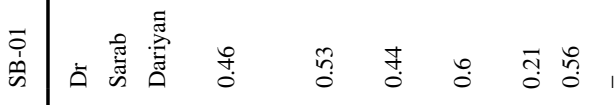

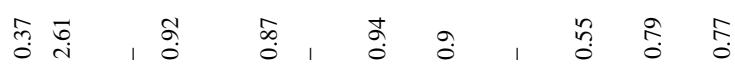

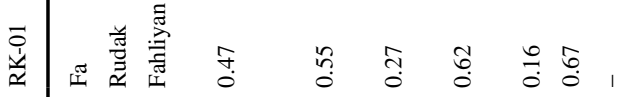

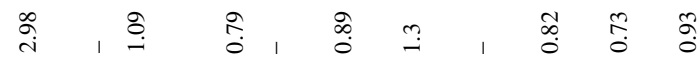

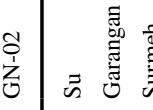

吾

กิ กั กิ

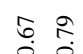

ஸे స়

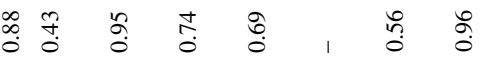

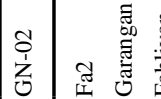

苞

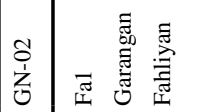
$\stackrel{a}{0} \quad \stackrel{m}{0} \quad \stackrel{m}{m}$

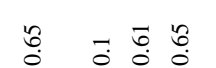

เิ.

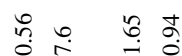

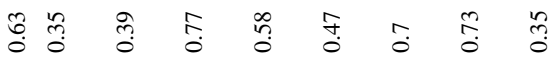

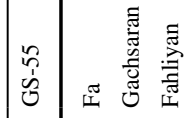
逽 $\sqrt[n]{0}$

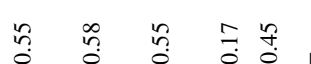

กิ ₹

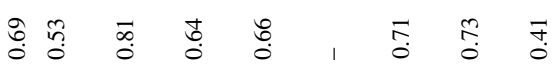

हี 密

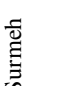

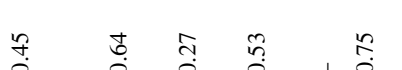

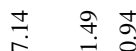

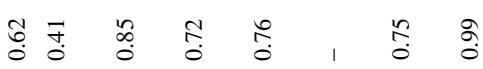
क ڤn

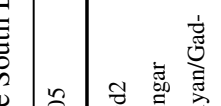

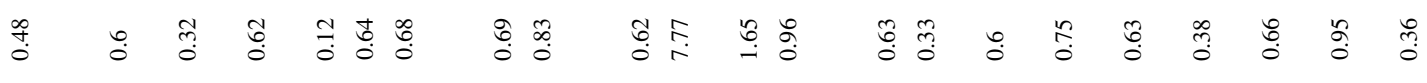

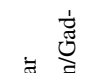

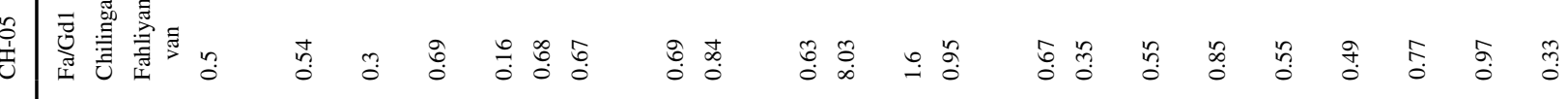

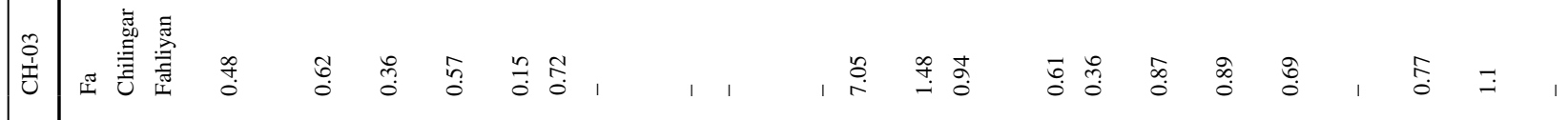




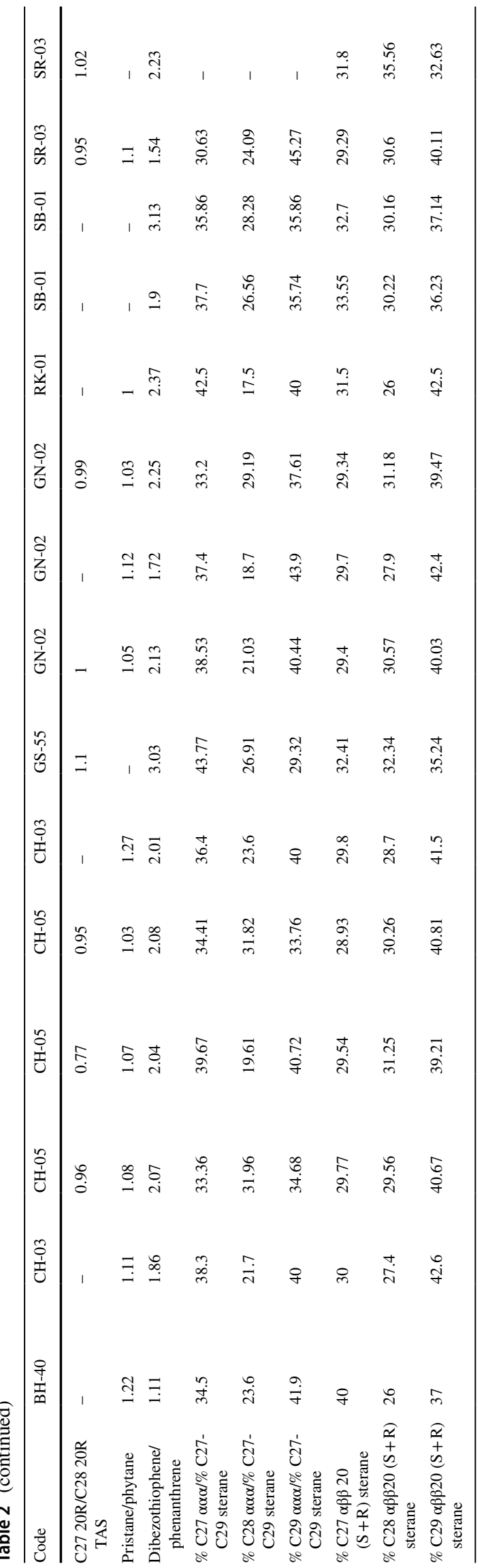

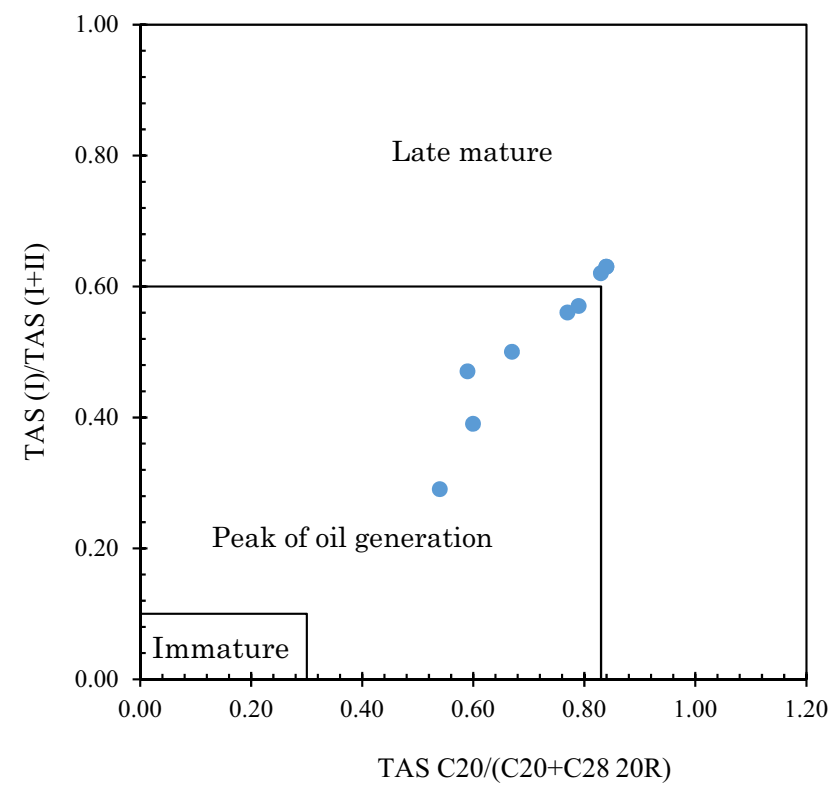

Fig. 5 Triaromatic steroid maturity parameters for the South Dezful Embayment's oils (after Mackenzie 1984)

source rock aging. This ratio ranges from 0.58 to 0.76 for our oil samples, consistent with generation from a source rock younger than the Middle Jurassic.

Much research has shown that the isotopic composition of the kerogen and originated oils changes with the geologic age. Analyses of the worldwide source rocks and oils indicate a gradual ${ }^{13} \mathrm{C}$ enrichment with decreasing age (Andrusevich et al. 1998; Peters et al. 2005). The $\delta^{13} \mathrm{C}$ of asphaltene varies from 27.4 to $26.8 \%$ o for studied oils (Table 2). This value can support that the oils are originated from Late Jurassic to Early Cretaceous rocks (Bordenave and Hegre 2010).

Possible source rock-oil relationships Asphaltene fraction in the migrated oils and source rock extracts has the most adjoining isotopic composition to the kerogen in the parent source rocks (Peters et al. 2005). However, the stable carbon isotopic composition of the saturated hydrocarbon fractions and the whole oil may be different from the precursor organic matter. Similar or the same composition may suggest short migration distances, limited contamination by other sources, small isotopic fractionations and low thermal maturation. In contrast, large isotopic differences between different fractions might indicate contributions from different source rocks in hydrocarbon charging. Therefore, the $\delta^{13} \mathrm{C}$ profiles of all fractions can be diagnostic in source-oil correlations and oil family classification (Galimov 1974; Peters et al. 2005; Stahl 1978).

In this study, stable carbon isotopic composition of the oil fractions was determined for oils from the Khami 


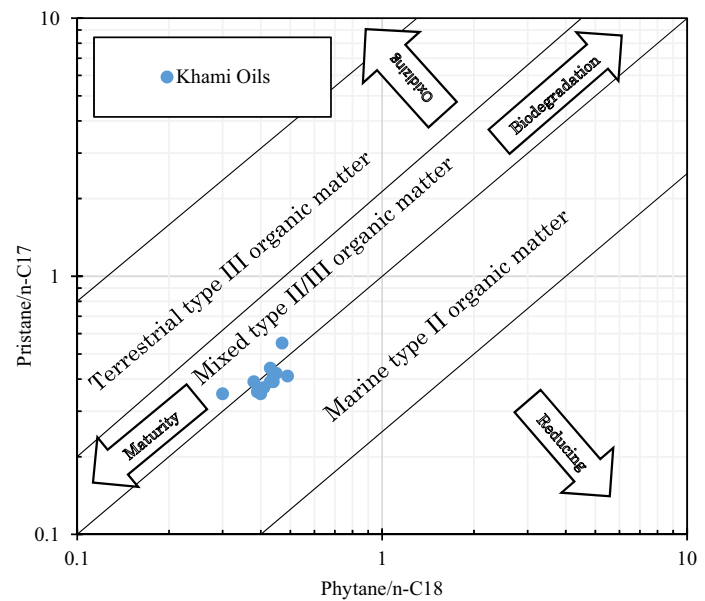

Fig. 6 Pristane $/ n-\mathrm{C}_{17}$ versus Phytane $/ n-\mathrm{C}_{18}$ for the South Dezful Embayment oils (after Peters et al. 1999)

reservoirs in the South Dezful Embayment. The $\delta^{13} \mathrm{C}$ of asphaltene fractions varies from -27.4 to $-26.8 \%$ (PDB) for the studied oils (Table 2). This isotopic homogeneity may suggest that the studied oils are derived from the same source rock or similar facies of different source rocks. Similar isotopic compositions were reported for kerogen concentrates obtained from Garau, Gadvan and Dariyan Formations (Bordenave and Hegre 2010). Therefore, we can conclude that the studied oils from the Southern Dezful Embayment were generated by Early Cretaceous source rocks. Similar conclusions were reached in the NW Persian Gulf basin, where Garau equivalent facies was defined as the most likely source for Khami Group oils (Baniasad et al. 2017).

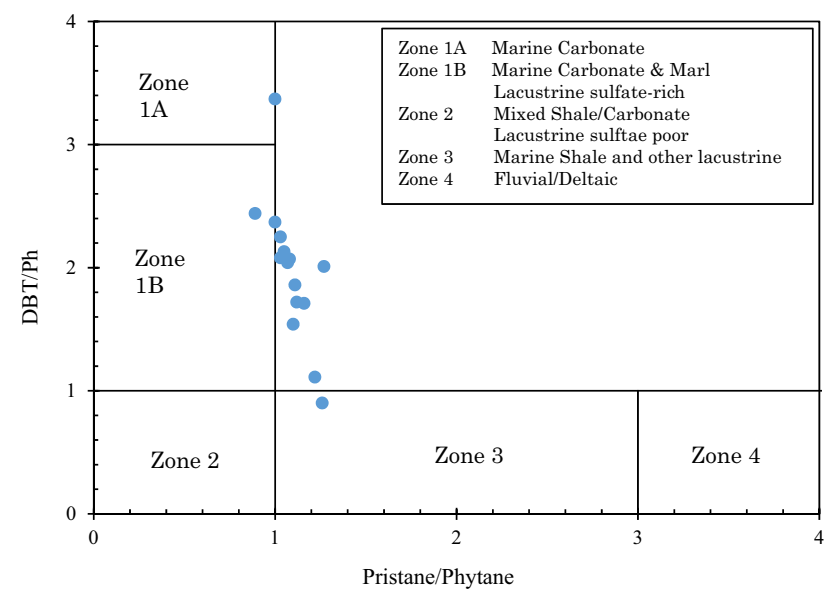

Fig. 7 Pristane/phytane versus dibezothiophene/phenanthrene for the South Dezful Embayment oils, indicating a marine carbonate/marl source rock with relatively high sulfur content (after Hughes et al. 1995)

\section{Source rock analysis}

In recent years, a number of potential source rock intervals, including the Pabdeh (Paleocene-Eocene), Gurpi (Santonian-Maastrichtian), Laffan (Coniacian), Kazhdumi (Albian), Kazhdumi Tongue (Aptian), Gadvan (Neocomian), Garau (Neocomian-Albian) and Sargelu (Alenian-Bathonian) Formations, have been described in the Dezful Embayment (Alizadeh et al. 2012; Bordenave 2002, 2014; Bordenave and Burwood 1990, 1995; Bordenave and Hegre 2005; Fouladvand and Alizadeh 2010; Opera et al. 2013). However, possible source rock(s) of the Khami Group reservoirs in the southernmost part of Dezful Embayment have not been considered in detail. In this study, we provide adequate geochemical information about these units and eventually introduce the most likely source rock that could generate oils accumulated in the Khami Group reservoir.

\section{Kazhdumi formation}

In the southernmost part of the Dezful Embayment, the Kazhdumi Formation is composed of thick (150-350 m) oxic to suboxic shales and marls with interbedded organicrich argillaceous limestones. The thickness reaches a minimum over the pre-Zagros paleo-high (Kharg-Mish structures) and increases southward (i.e., into the Binak-Borazjan depression) and westward (i.e., into the Bibi Hakimeh and Gachsaran anticlines) based on wireline log data and seismic profiles. The prolific facies of the formation with an average thickness of $60 \mathrm{~m}$ were deposited during a transgressive system tract (TST) according to the conventional logs and Rock-Eval data. The early oil generation stage has reached in the Binak-Borazjan depression, whereas in other parts the formation remains in the immature stage. Poor to fair type III and mixed II/III kerogen with low organic matter content (TOC $<1.7 \%$ ) (Fig. 9) suggest that except in the southern area (i.e., the Binak-Borazjan depression) the Kazhdumi Formation could not have a substantial contribution in petroleum generation and expulsion. Nevertheless, this formation would charge the structures close to Binak-Borazjan depression. This hypothesis is obviously supported by the presentday distribution of oils in the South Dezful Embayment. Structures located in the south (e.g., Binak, Shur, Nargesi, Kilur Karim, Golkhari and Siah Makan) have considerable oil reserves in the Asmari and Sarvak horizons. However, anticlines on the northern boundary (e.g., Shahranjan, Seghanat, Sarab and Dara) only possess some oil/gas shows in the Asmari and Sarvak levels.

The main biomarker characteristics of the Kazhdumi Formation are summarized as $\mathrm{C}_{29} / \mathrm{C}_{30}$ hopane $<1, T_{\mathrm{s}} / T_{\mathrm{m}}<1$ (argillaceous limestone with low maturity), $\mathrm{C}_{27} / \mathrm{C}_{29}$ sterane $<1$ (considerable terrigenous input), low gammacerane content together with low $\mathrm{C}_{35} / \mathrm{C}_{34}$ homohopane ratio 
Fig. 8 Typical hopane (a) and sterane (b) mass chromatograms of Khami oils from the South Dezful Embayment
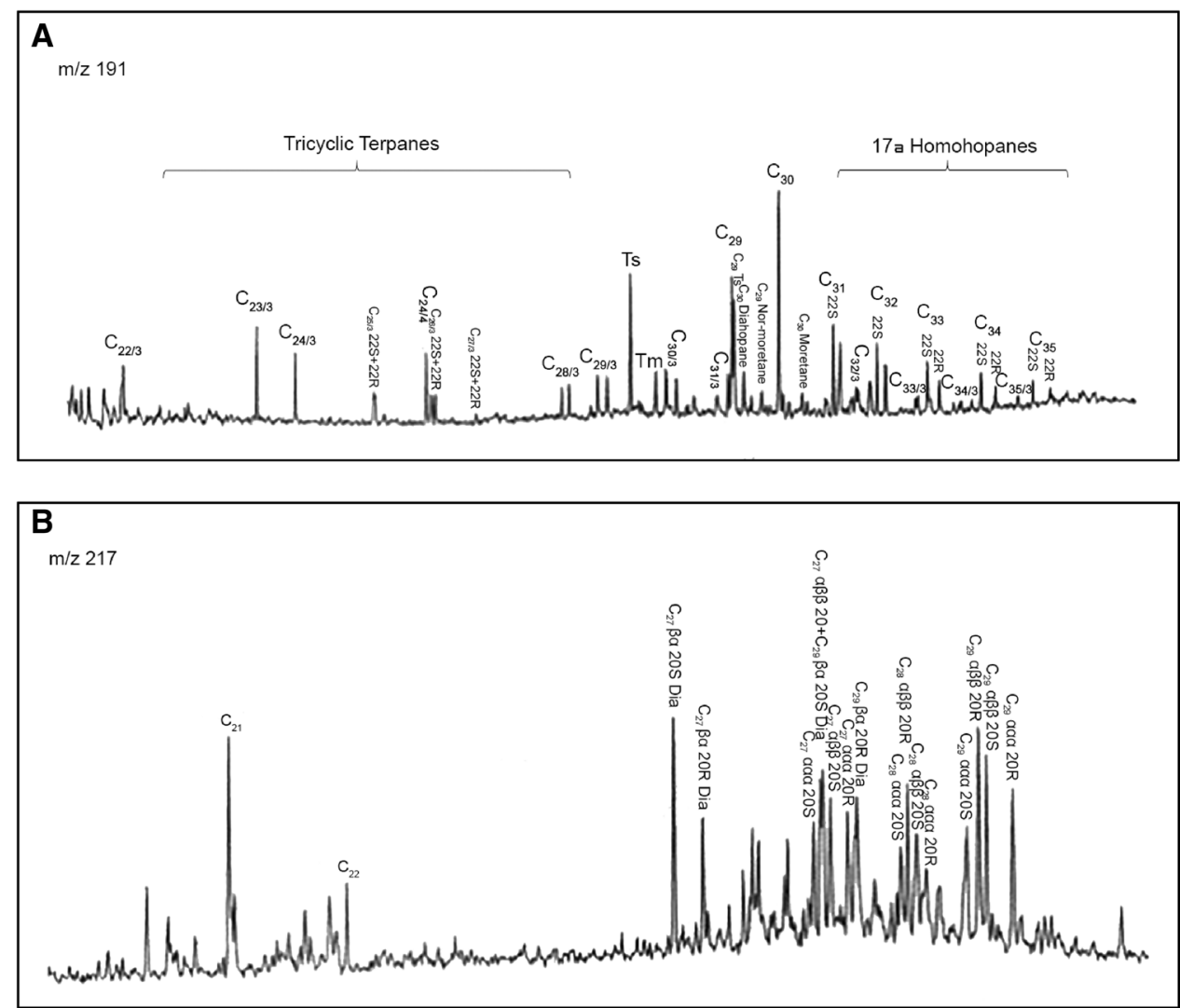

(suboxic to semi-anoxic environment), $\mathrm{C}_{28} / \mathrm{C}_{29} \sim 0.6$ and the absence of oleanane. It is essential to note that the mentioned biomarker features are seen exactly in oils from Asmari and Sarvak reservoirs in the South Dezful Embayment (structures related to the Binak-Borazjan depression). This supports the conclusion that the main source rock in the Upper Cretaceous-Tertiary petroleum system is the Kazhdumi Formation. Nonetheless, the biomarker fingerprints reported here show many differences from those aforementioned for Khami Group oils in the South Dezful Embayment. Major biomarker and isotopic inconsistencies imply that Kazhdumi Formation could not participate in charging Khami reservoirs in the studied area. Based on our findings, the main Kazhdumi kitchen is located in the Binak-Borazjan depression and North Dezful Embayment.

It should be emphasized that the Kazhdumi Formation could have played a key role in the Upper Jurassic-Lower Cretaceous petroleum system as an effective final seal (i.e., the dysmigrating oils from the Khami Group reservoirs were prevented from entering the overlying Sarvak reservoirs).

\section{Dariyan formation}

The Aptian-aged Lower Dariyan-Kazhdumi Tongue organic-rich successions, with an upward shallowing facies, were deposited under transgressive marine conditions. From base to top, the TOC contents decrease as the pelagic fauna changes upward to shallow marine

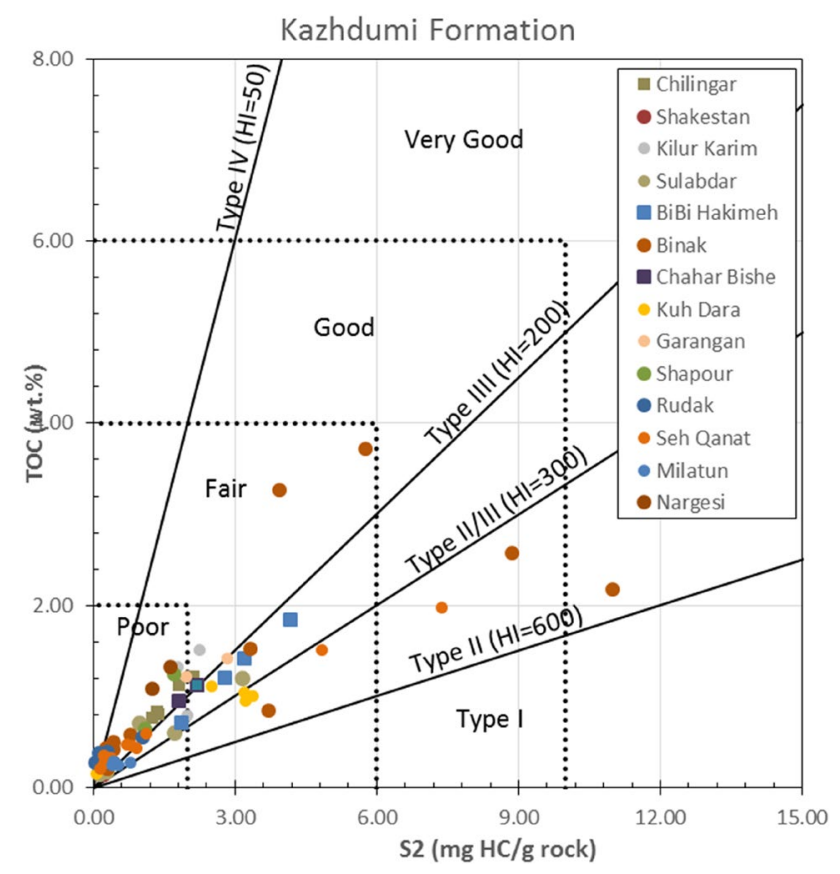

Fig. $9 \mathrm{~S}_{2}$ versus TOC diagram of Kazhdumi selected samples from South Dezful Embayment (after Dahl et al. 2004) 
facies in the South Dezful Embayment. The Kazhdumi Tongue comprises a uniform thickness of $70 \mathrm{~m}$ across the study area with shales at the bottom and argillaceous limestone at the top. The Rock-Eval analysis shows mainly type III organic matter with fair generative potential (Fig. 10). However, in Binak-Borazjan depression more organic-rich marine facies is expected since deep basinal facies of the Kazhdumi tongue could be developed (van Buchem et al. 2001).

\section{Gadvan formation}

Based on comprehensive geological and sequence stratigraphic study conducted in the South Dezful Embayment and Fars Province, the maximum thickness of Gadvan Formation was found in the North Dezful Embayment (up to $250 \mathrm{~m}$ ), while in the South Dezful Embayment it drops significantly to less than $80 \mathrm{~m}$ (van Buchem et al. 2001).

According to Rock-Eval pyrolysis data, the Lower Gadvan Formation shows good source rock potential as a consequence of the intermittent reducing conditions in its depositional environment (van Buchem et al. 2001). Within the studied area, the Binak-Borazjan depression is the only place where the Gadvan Formation comprises good generative potential $\left(\mathrm{S}_{2}>5 \mathrm{mg} \mathrm{HC} / \mathrm{g}\right.$ rock and TOC $\left.>1 \%\right)$

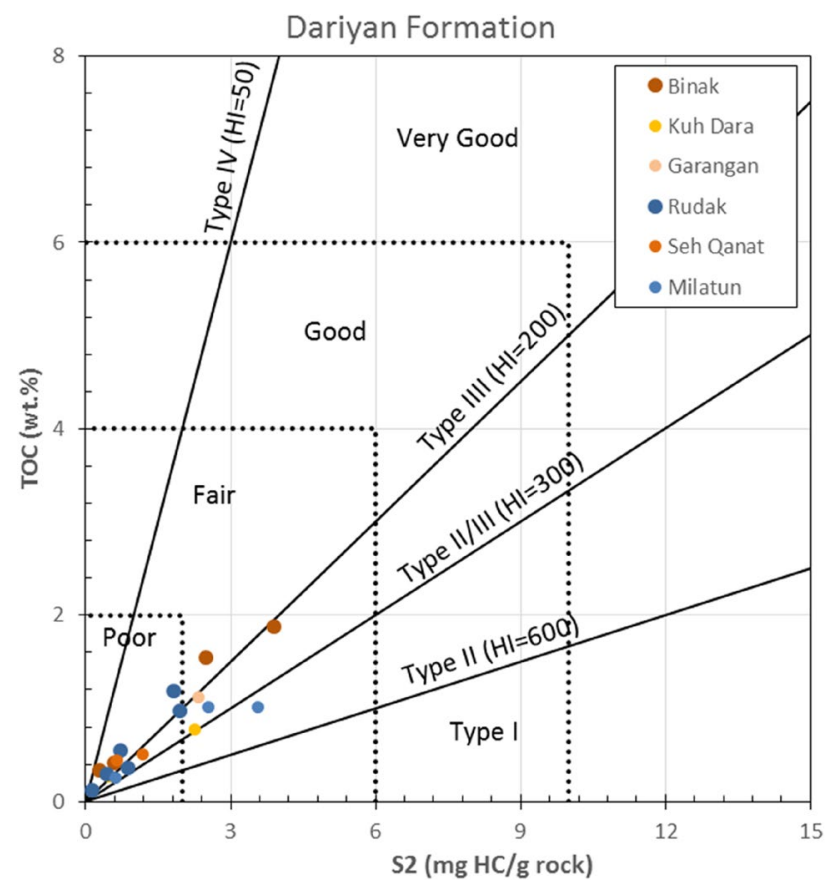

Fig. $10 \mathrm{~S} 2$ versus TOC diagram of the Dariyan Formation based on available samples from the South Dezful Embayment (after Dahl et al. 2004)

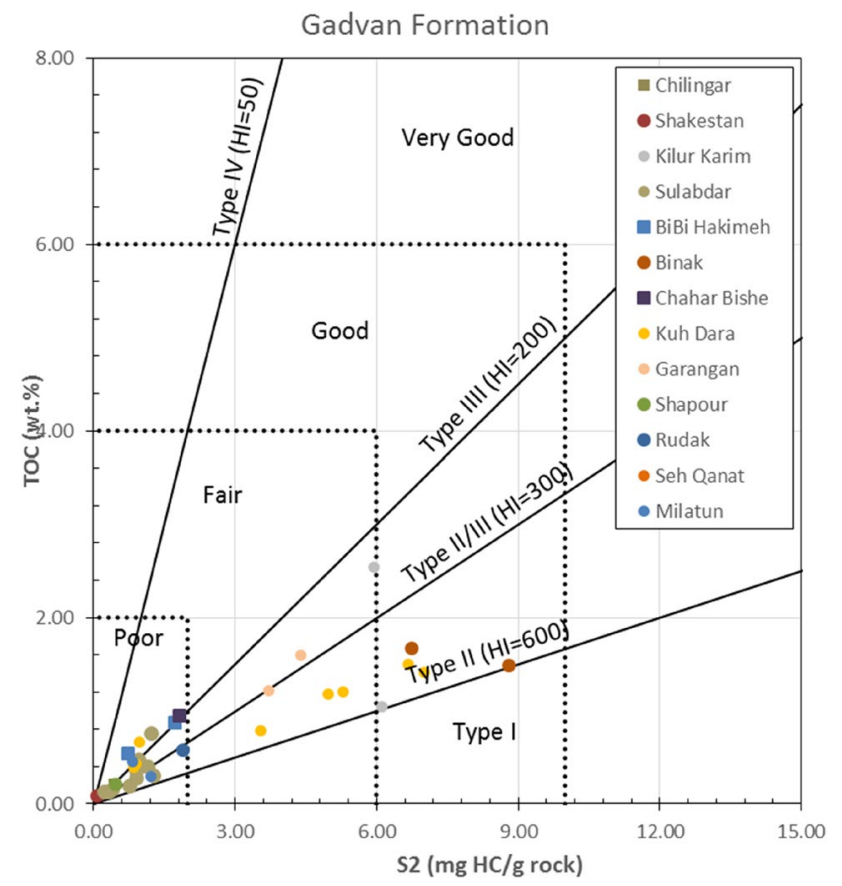

Fig. $11 \mathrm{~S}_{2}$ versus TOC diagram of the Gadvan Formation based on available samples from the South Dezful Embayment (after Dahl et al. 2004)

and indicates type II organic-rich facies $(\sim 100 \mathrm{~m}$ thickness) (Fig. 11).

\section{Summary and conclusions}

An inclusive geological and geochemical investigation conducted on more than 20 structures, including dry anticlines and gas/oil fields, revealed the following facts about the unfamiliar Khami group reservoirs in the southernmost part of Dezful Embayment.

- The typical fingerprints of Khami Group oils in the South Dezful Embayment show that the source rock was deposited in an open marine intra-shelf basin with semi-anoxic conditions prevailing at the bottom.

- The maturity of the Khami oil's source rock(s) is consistent with the peak of the oil generation window.

- A similar geochemical fingerprint for the oils in the Surmeh, Fahliyan, Gadvan and Dariyan reservoirs in our study area suggests that identical source rock has contributed to charge these reservoirs.

- Based on the geochemical and geological constraints, the migration pathways are suggested to be from the deep mature areas in the west (i.e., the Pazanan-Rag Sefid depression) and the south (i.e., the Binak-Borazjan depression) of the study area toward regionally paleo- 
high structures (i.e., Kharg-Mish area). In contrast, the eastern and northern parts received only limited hydrocarbon charges due to the absence of rich and mature source rock facies.

- Based on the existing geochemical information, we can conclude that the Upper Jurassic-Lower Cretaceous petroleum system is related to the Lower Cretaceous source rocks (i.e., the Gadvan, Lower Dariyan and Garau equivalent facies of Fahliyan (?) Formations) in the South Dezful Embayment.

- The Surmeh-Fahliyan carbonates play a major role as the main reservoir rocks for generated hydrocarbons, while the thick Kazhdumi shales form the final seal of this petroleum system. Subordinate reserves in the Dariyan and Khalij carbonates could be formed due to the locally effective seals, i.e., Hith and Gadvan Formations.

Acknowledgements The authors would like to thank the National Iranian Oil Company (Exploration Directorate) for providing the data and permission to publish the results. The Petroleum Geology and Geochemistry Research Center (PGGRC) is acknowledged for providing some analytical data. We thank respectful editors and anonymous reviewers for their insights. We are also immensely grateful to these esteemed persons for their comments on an earlier version of the manuscript.

Open Access This article is licensed under a Creative Commons Attribution 4.0 International License, which permits use, sharing, adaptation, distribution and reproduction in any medium or format, as long as you give appropriate credit to the original author(s) and the source, provide a link to the Creative Commons licence, and indicate if changes were made. The images or other third party material in this article are included in the article's Creative Commons licence, unless indicated otherwise in a credit line to the material. If material is not included in the article's Creative Commons licence and your intended use is not permitted by statutory regulation or exceeds the permitted use, you will need to obtain permission directly from the copyright holder. To view a copy of this licence, visit http://creativecommons.org/licenses/by/4.0/.

\section{References}

Abeed Q, Littke R, Strozyk F, Uffmann AK (2013) The Upper Jurassic-Cretaceous petroleum system of southern Iraq: a 3-D basin modelling study. GeoArabia 18:179-200

Al-Husseini M (2008) Middle East geological time scale 2008: Cenozoic Era, Cretaceous and Jurassic Periods of Mesozoic Era. GeoArabia 13(4):185-188

Alizadeh B, Maroufi K, Fajrak M (2018) Hydrocarbon reserves of Gachsaran oilfield, SW Iran: geochemical characteristics and origin. Mar Petrol Geol 92:308-318

Alizadeh B, Sarafdokht H, Rajabi M, Opera A, Janbaz M (2012) Organic geochemistry and petrography of Kazhdumi (AlbianCenomanian) and Pabdeh (Paleogene) potential source rocks in the southern part of the Dezful Embayment, Iran. Org Geochem 49:36-46

Alsharhan A (2014) Petroleum systems in the Middle East geological society, vol 392. Special Publications, London, pp 361-408
Andrusevich V, Engel M, Zumberge J, Brothers L (1998) Secular, episodic changes in the stable carbon isotope composition of crude oils. Chem Geol 152:59-72

Bahroudi A, Talbot C (2003) The configuration of the basement beneath the Zagros Basin. J Petrol Geol 26:257-282

Baniasad A, Rabbani AR, Moallemi SA, Soleimany B, Rashidi M (2017) Petroleum system analysis of the northwestern part of the Persian Gulf, Iranian sector. Org Geochem 107:69-85

Beydoun Z, Clarke MH, Stoneley R (1992) Petroleum in the Zagros Basin: a late tertiary foreland basin overprinted onto the outer edge of a vast hydrocarbon-rich paleozoic-Mesozoic passive margin shelf. In: Macqueen RW, Leckie DA (eds) Memoir 55: Foreland Basins and Fold Belts. Chapter 11. American Association of Petroleum Geologists (AAPG), pp 309-339

Beydoun ZR (1993) Evolution of the northeastern Arabian plate margin and shelf: hydrocarbon habitat and conceptual future potential. Rev Inst Fr Pét 48:311-345

Bordenave M (2002) The Middle Cretaceous to Early Miocene petroleum system in the Zagros Domain of Iran, and its prospect evaluation. In: AAPG annual meeting. American Association of Petroleum Geologists Houston, pp 1-9

Bordenave M (2014) Petroleum systems and distribution of the oil and gas fields in the Iranian part of the Tethyan region. AAPG Memoir 106:505-540

Bordenave M, Burwood R (1990) Source rock distribution and maturation in the Zagros orogenic belt: the provenance of the Asmari and Bangestan reservoir oil accumulations. Org Geochem 16:369-387

Bordenave M, Burwood R (1995) The Albian Kazhdumi Formation of the Dezful Embayment, Iran: one of the most efficient petroleum generating systems. In: Petroleum source rocks. Springer, pp 183-207

Bordenave M, Hegre J (2005) The influence of tectonics on the entrapment of oil in the Dezful Embayment, Zagros Foldbelt. Iran J Petrol Geol 28:339-368

Bordenave M, Hegre J (2010) Current distribution of oil and gas fields in the Zagros Fold Belt of Iran and contiguous offshore as the result of the petroleum systems. Geol Soc Lond Spec Publ 330:291-353

Boreham C, Crick I, Powell T (1988) Alternative calibration of the Methylphenanthrene Index against vitrinite reflectance: application to maturity measurements on oils and sediments. Org Geochem 12:289-294

Cohen K, Finney S, Gibbard P, Fan J-X (2013) The ICS international chronostratigraphic chart. Episodes 36:199-204

Cole G, Carrigan W, Colling E, Halpern H, Al-Khadhrawi M, Jones P (1994) The organic geochemistry of the Jurassic petroleum system in Eastern Saudi Arabia. In: Embry AF, Beauchamp B, Glass DJ (eds) Memoir 17: Pangea: global environments and resources. Canadian Society of Petroleum Geologists, Calgary, Alberta, Canada, pp 413-438

Connan J, Bouroullec J, Dessort D, Albrecht P (1986) The microbial input in carbonate-anhydrite facies of a sabkha palaeoenvironment from Guatemala: a molecular approach. Org Geochem 10:29-50

Dahl B, Bojesen-Koefoed J, Holm A, Justwan H, Rasmussen E, Thomsen E (2004) A new approach to interpreting Rock-Eval S2 and TOC data for kerogen quality assessment. Org Geochem 35:1461-1477

Fard IA, Braathen A, Mokhtari M, Alavi SA (2006) Interaction of the Zagros Fold-Thrust Belt and the Arabian-type, deep-seated folds in the Abadan Plain and the Dezful Embayment, SW Iran. Petrol Geosci 12:347-362

Fouladvand R, Alizadeh B (2010) Organic petrography, geochemical behavior, and paleo depositional environment of binak oilfield, SW Iran. In: Paper presented at the: the 1st international applied

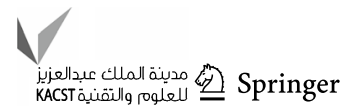


geological congress. Department of Geology, Islamic Azad University - Mashad Branch, Iran, 26-28 April 2010

Galimov EM (1974) Organic geochemistry of carbon isotopes. In: Tissot B, Bienner F (eds) Advances in organic. Editions Technip, Paris, pp 439-452

Gradstein FM, Ogg J, Schmitz M, Ogg G (2009) International stratigraphic chart. International commission on stratigraphy

Grantham P, Wakefield L (1988) Variations in the sterane carbon number distributions of marine source rock derived crude oils through geological time. Org Geochem 12:61-73

Hessami K, Koyi H, Talbot CJ (2001) The significance of strike-slip faulting in the basement of the Zagros fold and thrust belt. J Petrol Geol 24:5-28

Holba A, Ellis L, Dzou I, Hallam A, Masterson W, Francu J, Fincannon A (2001) Extended tricyclic terpanes as age discriminators between Triassic, Early Jurassic and Middle-Late Jurassic oils. In: 20th international meeting on organic geochemistry. EAOG Nancy, France, p 464

Huang H, Pearson MJ (1999) Source rock palaeoenvironments and controls on the distribution of dibenzothiophenes in lacustrine crude oils, Bohai Bay Basin, eastern China. Org Geochem 30:1455-1470

Hughes WB, Holba AG, Dzou LI (1995) The ratios of dibenzothiophene to phenanthrene and pristane to phytane as indicators of depositional environment and lithology of petroleum source rocks. Geochim Cosmochim Acta 59:3581-3598

James G, Wynd J (1965) Stratigraphic nomenclature of Iranian oil consortium agreement area. AApG Bull 49:2182-2245

Letouzey J, Sherkati S (2004) Salt movement, tectonic events, and structural style in the central Zagros fold and thrust belt (Iran). In: Salt-sediment interactions and hydrocarbon prospectivity: 24th annual research conference, Gulf Coast Section, SEPM Foundation. pp 444-463

LGC (2002) Geochemical analysis of cores and crude oils from Iran. Internal LGC report Unpublished

Mackenzie A, Hoffmann C, Maxwell J (1981) Molecular parameters of maturation in the Toarcian shales, Paris Basin, France-III Changes in aromatic steroid hydrocarbons. Geochim Cosmochim Acta 45:1345-1355

Mackenzie AS (1984) Applications of biological markers in petroleum geochemistry. Adv Petrol Geochem 1:1-210

Moldowan JM, Seifert WK, Gallegos EJ (1985) Relationship between petroleum composition and depositional environment of petroleum source rocks. AAPG Bull 69:1255-1268

Moldowan JM, Sundararaman P, Schoell M (1986) Sensitivity of biomarker properties to the depositional environment and/or source input in the Lower Toarcian of SW-Germany. Org Geochem 10:915-926

Murris R (1980) Middle East: stratigraphic evolution and oil habitat. AAPG Bull 64:597-618

Nairn A, Alsharhan A (1997) Sedimentary basins and petroleum geology of the Middle East. Elsevier, Amsterdam

Navabpour P, Barrier E (2012) Stress states in the Zagros fold-andthrust belt from passive margin to collisional tectonic setting. Tectonophysics 581:76-83

Opera A, Alizadeh B, Sarafdokht H, Janbaz M, Fouladvand R, Heidarifard MH (2013) Burial history reconstruction and thermal maturity modeling for the middle cretaceous-early Miocene petroleum System, southern Dezful Embayment, SW Iran. Int J Coal Geol 120:1-14
Peters K (1999) Biomarkers: assessment of thermal maturity. Kluwer Academic Publishers, Boston

Peters KE, Fraser TH, Amris W, Rustanto B, Hermanto E (1999) Geochemistry of crude oils from eastern Indonesia. AAPG Bull 83:1927-1942

Peters KE, Peters KE, Walters CC, Moldowan J (2005) The biomarker guide, vol 1. Cambridge University Press, Cambridge

Pollastro RM (2003) Total petroleum systems of the Paleozoic and Jurassic, Greater Ghawar Uplift and adjoining provinces of central Saudi Arabia and northern Arabian-Persian Gulf. US Department of the Interior, US Geological Survey, Reston

Radke M (1983) The methylphenanthrene index (MPI): a maturity parameter based on aromatic hydrocarbons. Adv Org Geochem 1981:504-512

Radke M (1988) Application of aromatic compounds as maturity indicators in source rocks and crude oils. Mar Petrol Geol 5:224-236

Radke M, Welte D, Willsch H (1986) Maturity parameters based on aromatic hydrocarbons: influence of the organic matter type. Org Geochem 10:51-63

Seifert WK, Moldowan JM (1980) The effect of thermal stress on source-rock quality as measured by hopane stereochemistry. Phys Chem Earth 12:229-237

Sepehr M, Cosgrove J (2004) Structural framework of the Zagros foldthrust belt. Iran Mar Petrol Geol 21:829-843

Sherkati S, Letouzey J (2004) Variation of structural style and basin evolution in the central Zagros (Izeh zone and Dezful Embayment). Iran Mar Petrol Geol 21:535-554

Stahl W (1978) Source rock-crude oil correlation by isotopic typecurves. Geochim Cosmochim Acta 42:1573-1577

Ten Haven H, De Leeuw J, Damsté JS, Schenck P, Palmer S, Zumberge J (1988) Application of biological markers in the recognition of palaeohypersaline environments. Geol Soc Lond Spec Publ 40:123-130

Ten Haven H, De Leeuw J, Rullkötter J, Damsté JS (1987) Restricted utility of the pristane/phytane ratio as a palaeoenvironmental indicator. Nature 330:641

Tissot B, Welte D (1984) Petroleum formation and occurrence: a new approach to oil and gas exploration. Springer, Berlin

van Buchem F et al. (2001) The petroleum systems of the Dezful Embayment and Northern Fars (south-west Iran). In: NIOC-IFP joint study research project

Waples D, Machihara T (1991) Biomarkers for geologists. In: AAPG methods in exploration series No. 9 American Association of Petroleum Geologists, Tulsa, Oklahoma

Ziegler MA (2001) Late Permian to Holocene paleofacies evolution of the Arabian Plate and its hydrocarbon occurrences. GeoArabia 6(3):445-504

Zumberge JE (1984) Source rocks of the La Luna Formation (Upper Cretaceous) in the Middle Magdalena Valley, Colombia. In: Palacas JG (ed) Study geology 18: petroleum geochemistry and source rock potential of carbonate rocks, American Association of Petroleum Geologists (AAPG), pp 127-133

Publisher's Note Springer Nature remains neutral with regard to jurisdictional claims in published maps and institutional affiliations. 